\title{
Factors influences on the survival and death of macrophages infected with Salmonella typhi
}

Kenji Hirose, Li-Cheng Zhao, Khan Abdul Quayum, Masaki Miyake, Yoshiaki Kawamura, Takayuki Ezaki.

\begin{abstract}
Abstrak
Dalam penelitian ini biakan jaringan makrofag manusia THP-1 diinfeksi dengan Salmonella typhi dan S. typhimurium. Apa yang terjadi dengan makrofag tersebut setelah infeksi oleh kedua patogen tersebut ternyata berbeda. Makrofag yang diinfeksi oleh S. typhi tetap hidup lebih dari 24 jam, sedangkan $80 \%$ makrofag yang diinfeksi oleh S. typhimurium mati dalam waktu 16 jam. Karakter apoptosis makrofag yang diinfeksi oleh kedua patogen tersebut juga berbeda. Proses apoptosis pada makrofag yang diinfeksi oleh S. typhimurium terjadi lebih awal daripada infeksi oleh S. typhi. Untuk mengetahui mengapa makrofag yang diinfeksi oleh S. typhi dapat bertahan lama, dilakukan analisis protein yang disekresi oleh S. typhi dan produksi TNF- $\alpha$ yang dihasilkan oleh makrofag yang sudah diinfeksi. Galur S. typhi dengan kapsul Vi dan galur yang Vi antigennya delesi ternyata mensekresi protein dengan profil berbeda. Tingkat transkripsi mRNA TNF- $\alpha$ dari kedua kelomipok makrofag inipun berbeda.
\end{abstract}

\begin{abstract}
Salmonella typhi and S. typhimurium were infected to human macrophage cell line THP-1. Fate of macrophage after infection of these two pathogenic species was different. Most of macrophages infected with S. typhi were survived even after $24 \mathrm{hr}$, however, $80 \%$ of macrophages infected with $\mathbf{S}$. typhimurium were dead after 16 hour. Apoptosis of macrophages infected with these two pathogens were also different. At early stage of infection with $\mathrm{S}$. typhimurium, macrophages were in apoptotic process but $\mathrm{S}$. typhi infected macrophages remained at normal stage. To find the reason why S. typhi infected macrophages can survive for a long time, we analyzed secreted proteins of S. typhi and TNF- $\alpha$ production of infected macrophages. Vi capsulated S. typhi strains and Vi deleted S. typhi strains had completely different secreted protein profiles. Level of transcribed $m R N A$ of $T N F$ - $\alpha$-was also remarkably different between macrophages infected with the two pathogens.
\end{abstract}

\section{INTRODUCTION}

Salmonella typhi is known as a facultative intracellular parasite and it can survive inside macrophages. But, the survival mechanism is still unclear. We previously reported that $\mathrm{Vi}$ capsular polysaccharide played an important role for $S$. typhi to survive inside macrophages, because $\mathrm{Vi}$ positive strains did not stimulate host macrophages and as a result, the macrophage did not produce TNF- $\alpha$.

In this study, we constructed rpoS mutant of $S$. typhi which was derived from $S$. typhi Vi positive strain (wild type) and analyzed the survival under various stress. The death of THP-1 cells infected with S. typhi wild type, $S$. typhi rpos mutant were also compared. S. typhi rpoS mutant could replicate inside THP-1 cells at the similar level with $S$. typhi wild type strain. However, S. typhi rpoS mutant caused cell death less

Department of Microbiology,

Gifu University, School of Medicine, Gifu, 500 Japan. extent to infected macrophage than S. typhi wild type strain.

\section{MATERIALS AND METHODS}

\section{Bacteria and cell line}

Salmonella typhi wild type (GIFU 10007), S. typhi Vi negative mutant (GIFU 10388), S. typhi rpos mutant (GIFU-PPP 330) and S. typhimurium (GIFU 12142) were used in this study. THP-1 cells, which derived from human monocytic leukemia, were used for infection assay.

\section{Cell staining}

Cell staining to distinguish live and dead cells was carried out with Live/Dead Eukolight Viability/cytotoxicity assay reagent provided from Molecular probe. Staining was performed according to the manufacture's instrument. After staining, cells were observed by a confocal laser scanning microscope. Live cells emitted green fluorescent, and dead cell showed red fluorescent after staining with this reagent. 


\section{Flowcytometric analysis}

S. typhi and S. typhimurium were cultured in L-broth for indicated time. Bacteria were stained with Live/Dead Eukolight Viability/cytotoxicity assay reagent and analyzed by flow cytometry (Bio Rad Co, Japan). Live bacteria were carefully gated by forward scatter and lateral scatter to remove dead bacteria. Live bacteria were analyzed by lateral scatter and FITC intensity.

\section{RT-PCR}

Bacterial mRNA was extracted from S. typhi after cultured for indicated time. cDNA was synthesized from mRNA by reverse transcriptase. sigma32, sigma38 and sigma70 detected by RT-PCR using specific primers.

\section{Phagocytosis assay}

Bacteria and THP- 1 cells were mixed in HBSS at the ratio of 50 bacteria to 1 cell, and then cells were incubated in $37^{\circ} \mathrm{C}$ for 1 hour. The cells were resuspended in complete medium with gentamicin to remove extracellular bacteria for $30 \mathrm{~min}$.

\section{Staining intracellular bacteria}

$\mathrm{Vi}$ antigen of $S$. typhi inside THP-1 cells were detected by rabbit anti-Vi polyclonal antibody and goat FITC conjugated-anti-rabbit IgG. THP-1 cells were stained with PE-conjugated anti-CD14 monoclonal antibody.

\section{RESULTS}

\section{S. typhi replication inside activated macrophages}

$S$. typhi Vi positive strain and Vi negative strain internalized into resting THP-1 cells almost the same level (data not shown). S. typhi Vi positive strain survived into resting THP-1 cells, whereas Vi negative $S$. typhi could not survive (Figure 1). S. typhimurium internalized to a greater extent than $S$. typhi strains and survived inside resting THP- 1 cells. However, in THP-1 cell which activated by IFN- $\gamma$, S. typhi strains and $S$. typhimurium did not survive in spite of the higher numbers of bacteria were internalized.

\section{S. typhi expressed Vi antigen inside THP-1 cell after infection}

We detected the Vi antigen of intracellular S. typhi. After invasion to THP-1 cells, $S$. typhi inside THP-1 cells were stained with rabbit anti Vi polyclonal anti-

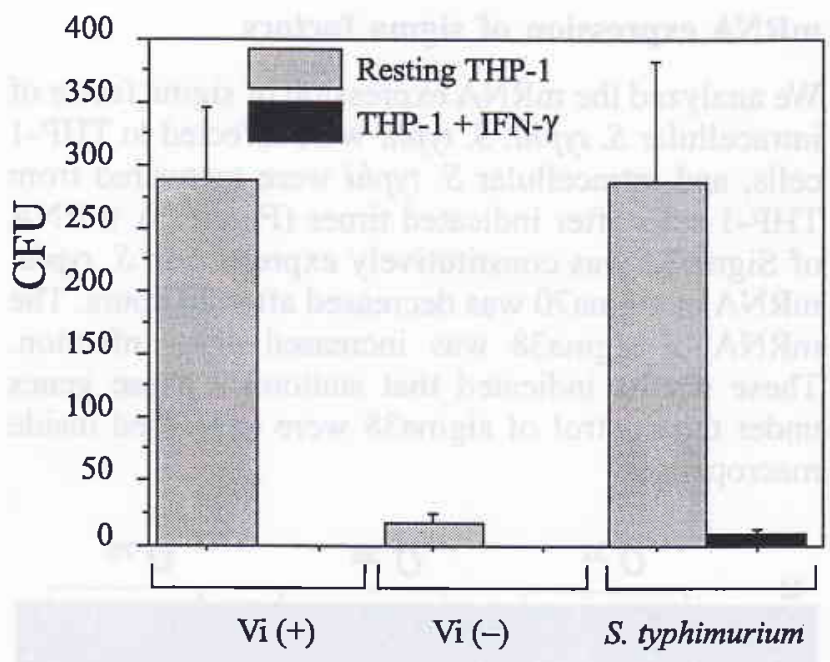

Figure 1. Replication of S. typhi and S. typhimurium inside resting and activated THP-1 cells.

Data were represented as mean \pm SEM.

body and FITC conjugated goat anti rabbit IgG. Intracellular $S$. typhi expressed Vi antigens even after infected into macrophages (Figure 2). S. typhi Vi positive strain recovered from THP-1 cells were only agglutinated with $\mathrm{Vi}$ antiserum but not with $\mathrm{O} 9$ antiserum. This means 09 antigen is completely masked with Vi antigen (data not shown). These data suggested that $S$. typhi inside macrophages continuously expressed $\mathrm{Vi}$ antigen after invasion into THP-1 cells.

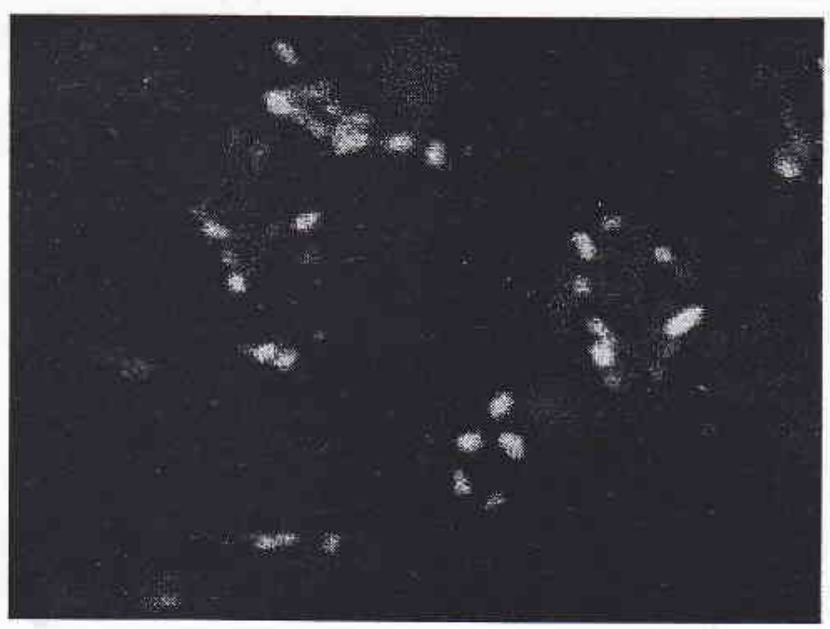

Figure 2. S. typhi expressed Vi antigen inside THP-1 cells.

S. typhi wild type was infected to THP-I cells. After infection, $V i$ antigen of S. typhi inside THP-1 cells was detected by rabbit anti-Vi polyclonal antibody and goat FITC conjugated-anti-rabbit IgG. THP-I cells were stained with PE-conjugated anti-CDI4 monoclonal antibody. 


\section{mRNA expression of sigma factors}

We analyzed the mRNA expression of sigma factor of intracellular S. typhi. S. typhi were infected to THP-1 cells, and intracellular $S$. typhi were recovered from THP- 1 cells after indicated times (Figure 3). mRNA of Sigma32 was constitutively expressed in S. typhi. mRNA of sigma70 was decreased after 20 hours. The mRNA of sigma38 was increased after infection. These results indicated that stationary phase genes under the control of sigma38 were expressed inside macrophages.

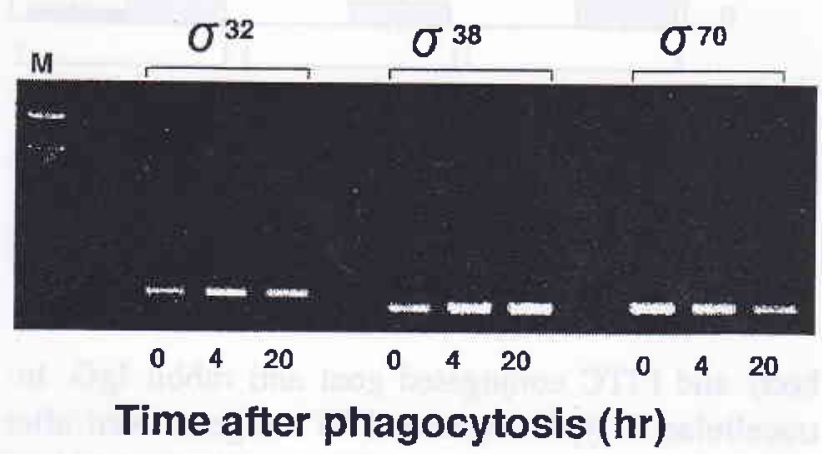

Figure 3. RT-PCR analysis of sigma factors of S. typhi in THP-1 cells.

\section{S. typhi survival in low $\mathrm{pH}$ condition}

The $S$. typhi Vi positive strain cultured stationary phase and log phase were cultured in the $L$ broth in pH 4 and the survival rate was compared (Figure 4). This low $\mathrm{pH}$ condition was expected to be similar to intracellular environment. Stationary phase bacteria were more resistant to intracellular low $\mathrm{pH}$ condition and $\log$ phase bacteria were sensitive and died within $60 \mathrm{~min}$. These results indicated that stationary phase $S$. typhi cells were more resistant in intracellular condition.

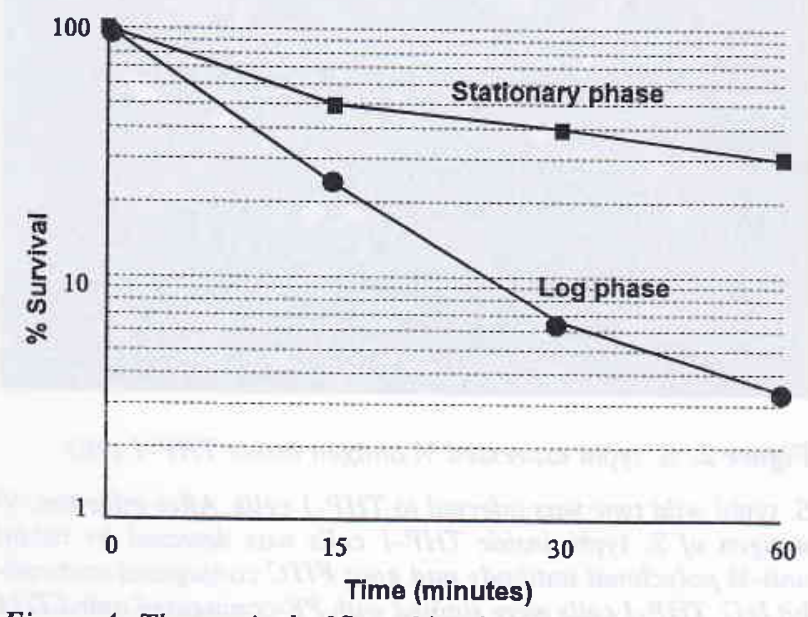

Figure 4. The survival of S. typhi cultured in $\mathrm{pH} 4$.

\section{Analysis of $S$. typhi viability by Flowcytometry}

S. typhi Vi positive strain was cultured in L-broth for 4, 8 and 24 hours. The strain was stained with Live / dead cell eukolight viability assay reagent, and bacteria were analyzed by flowcytometer. After 8 hours culture, $S$. typhi cells were separated into two populations shown in Figure 5, however, S. typhimurium remained single population even after 24 hours. The upper population indicated brightly stained bacteria, and lower population indicated faintly stained bacteria. The bacteria brightly stained in green color means that these bacteria are still active. Another group of bacteria stained in faint green means that viability were decreased. These results suggested that $S$. typhi might change the metabolic phase and became stationary phase in 24 hours when cultured in ordinary laboratory media.

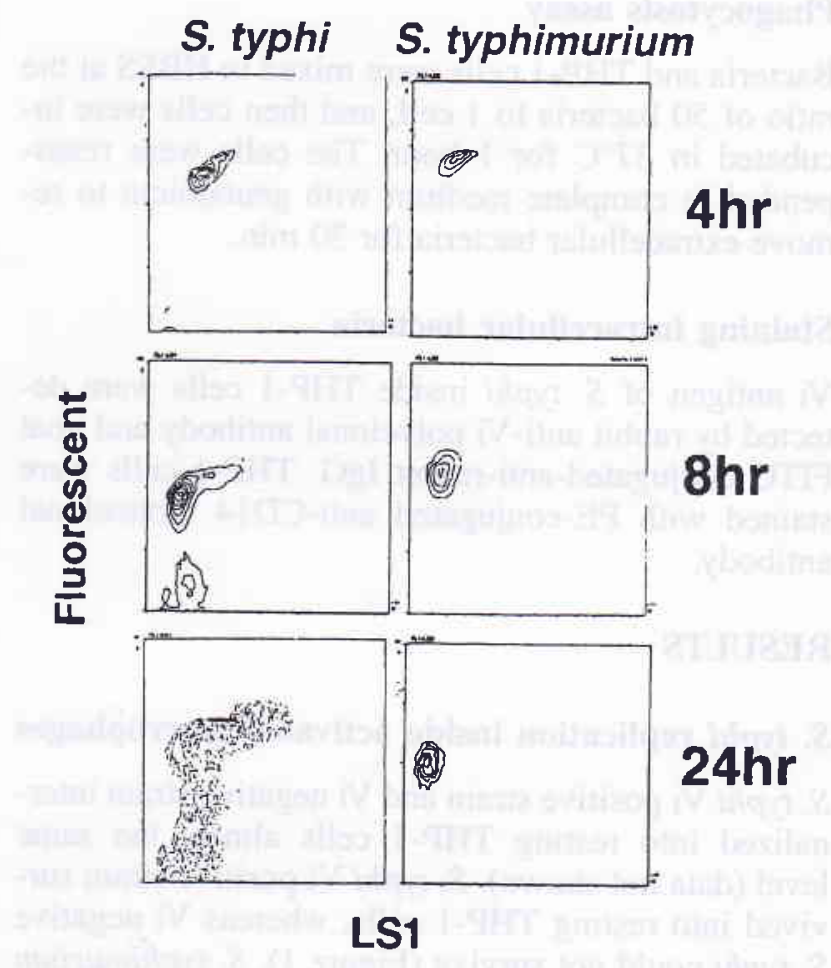

Figure 5. Flowcytometric analysis of S. typhi and S. typhimurium cultured in L-broth for 4, 8, and 24 hours. $X$ axis represents the intensity of lateral scatter, and $Y$ axis represents the intensity of FITC.

\section{Host macrophage death after invasion of $S$. typhi rpoS mutant}

We compared host cell death after $S$. typhi invasion into macrophages cell line THP-1 cells. $S$. typhimurium, $S$. typhi wild type and $S$. typhi rpoS mu- 
tant were infected to THP-1 cells and the cells were incubated for 1, 4, 16 and 32 hours. After incubation, THP- 1 cells were stained with Live/dead cell eukolight viability assay reagent, then the cells were observed by confocal laser microscope and generated into images. The live cells and dead cells were counted. The percentages of dead THP- 1 cells after invasion were shown in Figure 6. After 32 hours incubation, S. typhimurium killed about $90 \%$ of THP-1 cells. But, S. typhi rpoS mutant were significantly less than $S$. typhi wild type strain. These results indicated that rpoS gene expression played an important role for the pathogenesis of $S$. typhi.

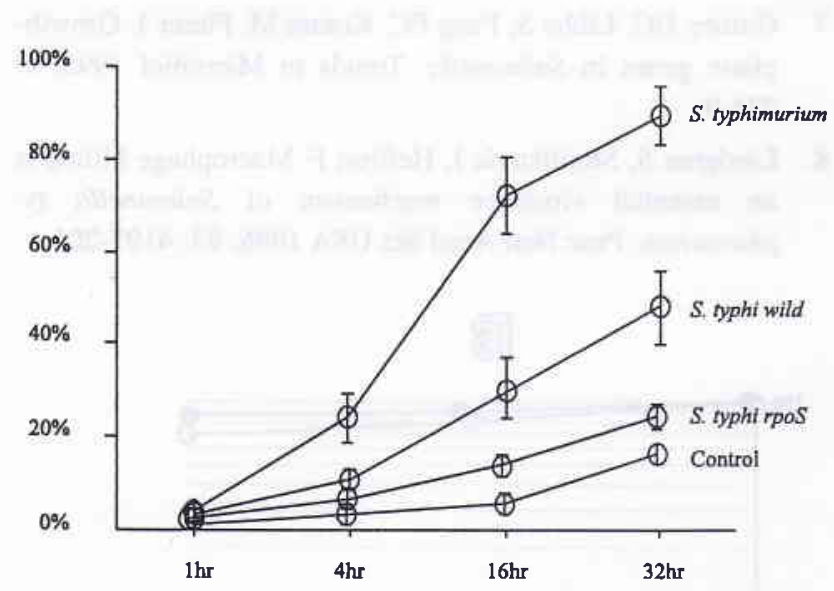

Figure 6. Host macrophage cell death after invasion of S. typhi strains and S. typhimurium.

Data were expressed as mean \pm SEM.

\section{S. typhi survivals in various culture conditions}

$S$. typhi wild type strain and rpoS mutant were compared on their survivals in various culture conditions. In Figure 7A, S. typhi wild type and rpoS mutant were cultured in L-broth. After culture transferring the cells into $\mathrm{pH} \mathrm{4}$, viable bacteria numbers were counted by the plating 15,30,60 min later. More than $90 \%$ of S. typhi rpos mutant were dead after $60 \mathrm{~min}$ in $\mathrm{pH} 4$ medium. This result indicated that $S$. typhi rpoS mutant is sensitive to low $\mathrm{pH}$ conditions. In Figure 7B, we compared intracellular replication inside THP-1 cells. $S$. typhi were infected to THP-1 cells and incubated for further 4 or 20 hours in RPMI1640 with $10 \%$ FBS. After incubation, cells were lysed and intracellular viable bacteria were counted. After 4 hour or 20 hours incubation, intracellular viable bacteria in THP-1 cells were almost at the same level at each point. In Figure 7C, S. typhi wild type strain and rpoS mutant were cultured in M9 medium for 5 days. All of $S$. typhi rpoS mutant were dead on day 4 after inoculation, whereas $20 \%$ of $S$. typhi wild type strain were still alive on day 5 . This result means $S$. typhi rpoS mutant is sensitive to starvation. In Figure 7D, $S$. typhi rpoS mutant and wild type were cultured in the medium containing $15 \mathrm{mM}$ of hydrogen peroxide. S. typhi rpoS mutant was rapidly died within $15 \mathrm{~min}$., however, $S$. typhi wild type strain was resistant to 15 $\mathrm{mM}$ hydrogen peroxide and $70 \%$ of bacteria were still viable after $60 \mathrm{~min}$. incubation. From these experiment, $S$. typhi rpoS mutant was sensitive to low $\mathrm{pH}$, starvation and hydrogen peroxide. This means that ropes gene expression might be essential for $S$. typhi to survive long time inside macrophages.

\section{DISCUSSION}

We previously reported that Vi capsular polysaccharide played an important role for $S$. typhi to survive inside macrophages. The macrophages infected with $S$. typhi Vi mutant or $S$. typhimurium produced a large amount of TNF- $\alpha$, whereas, Vi positive strains did not stimulate host macrophages to produce TNF- $\alpha$, because Vi antigen covered the bacterial surface LPS and $\mathrm{Vi}$ antigen prevent the LPS from macrophage CD14.

In this study, we constructed $S$. typhi rpoS mutant which derived from $S$. typhi Vi positive strain (wild type) and compared the survival of $S$. typhi wild type, $S$. typhi Vi mutant, S. typhi rpoS mutant.

S. typhi could not survive in the activated THP-1 cells (Figure 1). The organisms, thus, internalizes into resting THP- 1 cells to survive inside the cells, and intracellular $S$. typhi continuously expressed $\mathrm{Vi}$ antigen inside THP-1 cells (Figure 2). Once entered into macrophages, sigma38 of $S$. typhi is induced inside THP-1 cells, and $S$. typhi might changes their metabolic phase to stationary phase. Stationary phase $S$. typhi is resistant to low $\mathrm{pH}$ (Figure 4) condition which is similar to intracellular conditions. S. typhi cultured in L-broth for 24 hours separated into two groups of bacteria (Figure 5), one population is still log phase bacteria, another population is changed into stationary phase. RpoS mutant was less toxic to host cell, and was sensitive to low $\mathrm{pH}$, starvation and hydrogen peroxide. RpoS gene might be required for the pathogenesis of $S$. typhi. From these data, we concluded that Vi positive $S$. typhi shift metabolic phase to stationary phase after invasion into macrophages to adapt to the intracellular environment, and continued to survive without stimulating host cell recognition systems. 
We did not show another evidence that Vi positive $S$. typhi strain produced less amount of secretory proteins into cultured media. Most of the secreted proteins were flagellar antigens. However, Vi negative strains produced almost equal level of secreted proteins to $S$. typhimurium. Thus, we expected that Vi negative $S$. typhi stimulated host immune system through complement system, and CD14. S. typhimurium also stimulated host cells, but this organism was serum resistant and more resistant to oxygen radicals.

\section{REFERENCES}

1. Hashimoto Y, Li N, Yokoyama H, Ezaki T. Complete nucleotide sequence and molecular characterization of viaB region encoding Vi antigen in Salmonella typhi. J Bacteriol 1993; 175: 4456-65.

2. Hirose K, Ezaki T, Miyake M, Li T, Khan AQ, Kawamura $Y$, et al. Survival of Vi-capsulated and Vi-deleted Salmonella typhi strains in cultured macrophage expressing different levels

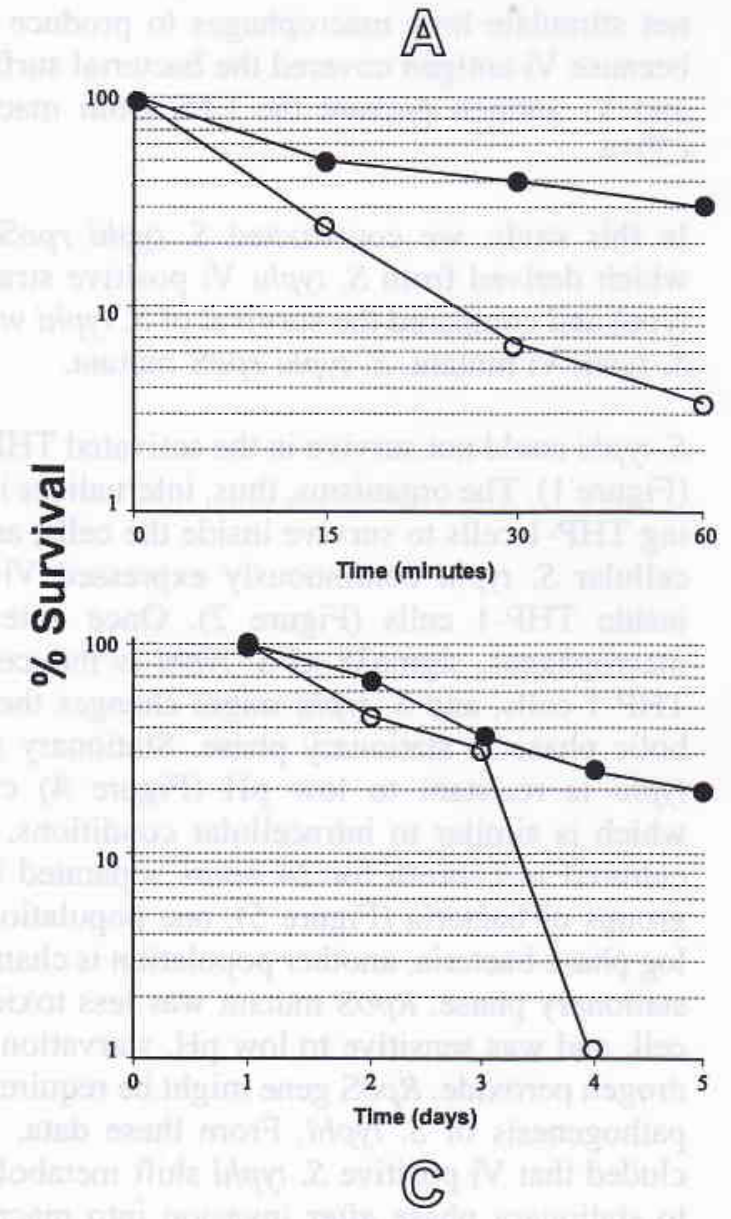

of CD14 antigen. FEMS Microbiol Lett 1997; 147: 259-65.

3. Kogoma T, Yura T. Sensitization of Escherichia coli cells to oxidative stress by deletion of the $\mathrm{rpoH}$ gene, which encodes the heat shock sigma factor. J Bacteriol 1992; 174: 630-2.

4. Staendner LH, Rohde M, Timmis KN, Guzman CA. Identification of Salmonella typhi promoters activated by invasion of eukaryotic cells. Mol Microbiol 1995; 18: 891-902.

5. Fang FC, Libby SJ, Buchmeier NA, Loewn PC, Switala J, Harwood J, et al. The alternative sigma factor KatF (RpoS) regulates Salmonella virulence. Proc Natl Acad Sci USA 1992; 89: 11978-82.

6. Groisman EA, Ochman H. How Salmonella became a pathogen. Trends in Microbiol 1997: 9: 343-9.

7. Guiney DG, Libby S, Fang FC, Krause M, Fierer J. Growthphase genes in Salmonella. Trends in Microbiol 1995; 7: 275-9.

8. Lindgren S, Stojiljkovic I, Heffron F. Macrophage killing is an essential virulence mechanism of Salmonella typhimurium. Proc Natl Acad Sci USA 1996; 93: 4197-201.

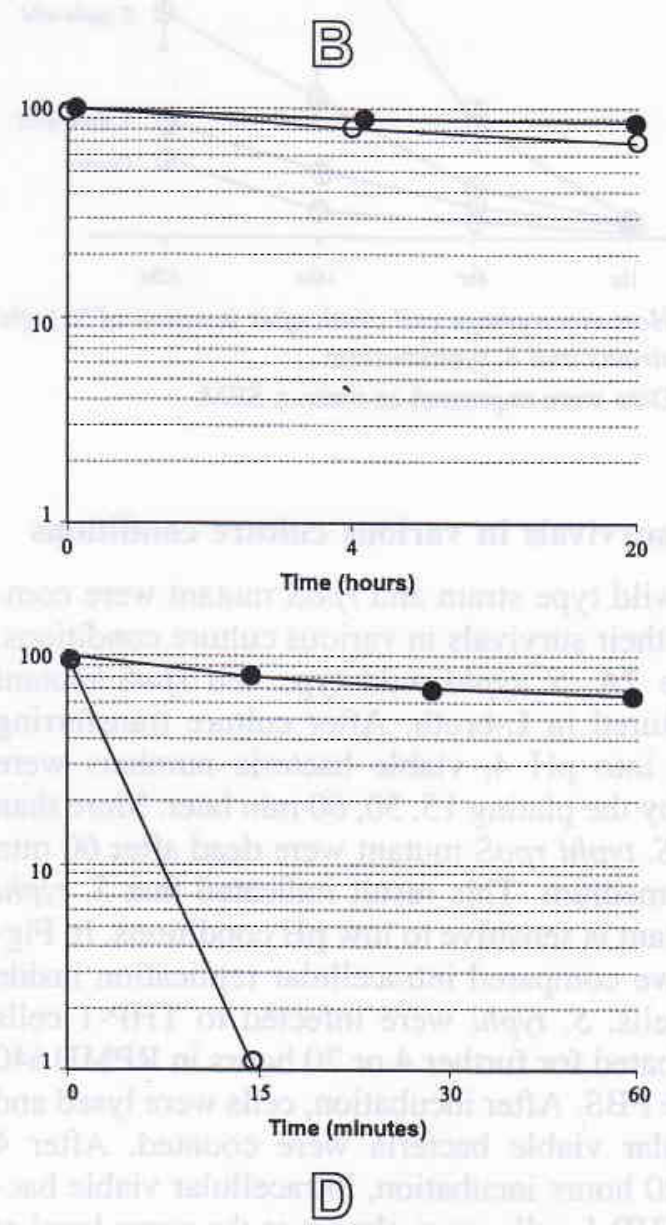

Figure 7. S. typhi survivals in various culture conditions. S. typhi wild type (-o-) and rpoS mutant (-o-) were cultured in low pH medium( $\mathrm{pH} 4)(\mathrm{A})$, cultured in $M 9$ medium (C), and cultured in the medium containing $15 \mathrm{mM}$ hydrogen peroxide $(D)$. The survival inside THP: 1 cells were compared between $\mathrm{S}$. typhi wild type and $\mathrm{rpoS}$ mutant $(B)$. 